\title{
Chronic Hepatitis C Treatment in a Thalassemia Major Patient: A Case Report
}

\author{
Talasemi Majörlü Hastada Kronik Hepatit C Tedavisi: Olgu Sunumu
}

\author{
Kaya Hüseyin SÜER1, Dilara INAN2 \\ ${ }^{1}$ Near East University Faculty of Medicine, Departments of Infectious Diseases and Clinical Microbiology, Nicosia, Turkish Republic of Northern Cyprus \\ 2 Akdeniz University Faculty of Medicine, Departments of Infectious Diseases and of Clinical Microbiology, Antalya, Turkey
}

\begin{abstract}
Thalassemia major patients with chronic hepatitis C have increased risk for developing fibrosis and hepatocellular carcinoma due to liver damage caused by these two diseases. Although the current treatment of chronic hepatitis is based on binary combinations, the use of ribavirin in combination with peginterferon alfa$2 a$ or $b$ in patients with hemoglobinopathies is not recommended by the treatment guidelines. However, it is observed that there have been changes in the applications presented in the guidelines over the years. This paper presents the outcomes and side effects of treatment given to thalassemia major patients with chronic hepatitis C. (Viral Hepatitis Journal 2014; 20(3): 134-137)

Key words: Chronic hepatitis $\mathrm{C}$, thalassemia major, ribavirin
\end{abstract}

Conflict of interest: The authors reported no conflict of interest related to this article.

\section{ÖZET}

Talasemi majör hastalarında saptanan kronik hepatitC olgularında karaciğer üzerinde iki hastalığın oluşturduğu hasar ile fibrozis ve hepatoselüler karsinom gelişme riski artmaktadır. Sadece kronik hepatit C tedavisinde kullanılan rehberlerin önerilerinde tedavi ikili kombinasyonlar ile başlamakla beraber hemoglobinopatisi olanlarda ribavirin kullanımı önerilmemektedir. Ancak yıllar içinde rehberlerdeki uygulamalarda değişikliler olduğu görülmektedir. Bu yazıda talasemi majör hastasında saptanan kronik hepatit $\mathrm{C}$ nedeniyle verilen tedavi, gelişen yan etkiler ve tedavi sonucu sunulmuştur. (Viral Hepatit Dergisi 2014; 20(3): 134-137)

Anahtar kelimeler: Kronik hepatit C, talasemi majör, ribavirin

Çıkar çatışması: Yazarlar bu makale ile ilgili olarak herhangi bir çıkar çatışması bildirmemişlerdir.

\section{Introduction}

Primary reason for the transmission of the Hepatitis C Virus $(\mathrm{HCV})$ infection is associated with infected blood and blood products. Therefore, the risk of developing $\mathrm{HCV}$ infection in transfusion-dependent patients with blood disorders can be expected to be high (1). In the United States, the prevalence of HCV was high in people who received a blood transfusion or blood products before 1992. After this date, the prevalence of transfusion-associated transmission of the infection started to decrease when routine screening for hepatitis $C$ was put into effect (2). In Turkey, as well as in the Turkish Republic of Northern Cyprus (TRNC), routine screening for hepatitis $\mathrm{C}$ in blood centres started in 1996. According to the Turkish Society of Haematology, the incidence of thalassemia in Turkey as a whole is at the rate of $2.1 \%$ whereas in Antalya, in the Southern Mediterranean Region of Turkey, this rate is five times higher at $10.2 \%$ (3).
The frequency of thalassemia in the Mediterranean basin is higher when compared to other geographical regions. Some of the patients received blood transfusions in this region even in the periods when screening for hepatitis was not yet performed. Therefore, the age groups of cases with hepatitis $C$ and thalassemia were found to be higher. Liver damage caused by these illnesses increases the risk of fibrosis and hepatocellular carcinoma development (4). In some previous studies, it has been shown that iron overload in the liver associated with thalassemia and $\mathrm{HCV}$ infection is an independent risk factor for fibrosis. In these cases of coexistence, the risk of fibrosis development increases remarkably and chronic hepatitis $\mathrm{C}$ develops secondarily to blood transfusion resulting in an increase in mortality and morbidity $(4,5,6,7)$. In the treatment of chronic hepatitis $\mathrm{C}$ patients, it is known that sustained virological response rate in interferon alpha monotherapy is low whereas the rate of recurrence is high (8). 
In the recommendations of the guidelines for the treatment of chronic hepatitis, although the treatment starts with binary combinations, ribavirin usage is not recommended for patients with hemoglobinopathies (9). However, it is observed that there have been changes in the applications presented in the guidelines over the years. The aim of this paper was to present outcomes and side effects of treatment given to thalassemia major patients with chronic hepatitis $\mathrm{C}$.

\section{Case}

A 21 year-old male thalassemia major patient, administered blood transfusion once or twice per month as a routine, was diagnosed with chronic hepatitis as a result of the examinations and tests performed when he applied to our outpatient clinic in August 2014 with the complaint of frailness. Hepatomegaly was detected during the medical examination and ultrasonography. There were no symptoms of jaundice portal hypertension, and splenomegaly on the skin and sclera. Laboratory investigations revealed the followings: HCV RNA: positive (we were not able to detect quantitative values in 2004), alanine transaminase (ALT): $287 \mathrm{U} / \mathrm{L}$, aspartate aminotransferase (AST): $145 \mathrm{U} / \mathrm{L}$, total bilirubin: $1.12 \mathrm{mg} / \mathrm{dL}$, haemoglobin $(\mathrm{Hb}): 9.7 \mathrm{gr} / \mathrm{dL}$, prothombin time (PTZ): 18.5 seconds, HBsAg, anti $\mathrm{HBs}$ and anti HIV: negative, and anti HAV: positive.

During follow-up, the fluctuating liver enzymes were found to be five to six times higher than before. Liver needle biopsy was not performed. He was HCV RNA-positive six months later, mainly as a result of his long prothrombin time and hence was treated with pegylated interferon alpha-2b 80 mcg per week.

The patient's treatment continued with the following findings in the 12th week of treatment: HCV RNA: negative, ALT: $112 \mathrm{U} / \mathrm{L}$, AST: $63 \mathrm{U} / \mathrm{L}$. In the $24^{\text {th }}$ and $48^{\text {th }}$ weeks, HCV RNA was negative, ALT and AST values were: ALT: 129 and $134 \mathrm{U} / \mathrm{L}, \mathrm{AST}: 78$ and 69 $U / L$, respectively.

At the $4^{\text {th }}$ month of treatment the patient's HCV-RNA, ALT and AST values were as follows: HCV-RNA: 1.320.000 UI/mL, ALT: $234 \mathrm{U} / \mathrm{L}, A S T: 113 \mathrm{U} / \mathrm{L}$ and genotype1b. Treatment with pegylated interferon alpha-2a 135 mcg per week was initiated. HCV RNA was found to be negative in the third, sixth and twelfth months. However, after that period, the patient was lost to follow-up.

In March 2012, the following results were detected: HCV RNA: 2.350.000 $\mathrm{IU} / \mathrm{mL}, A L T: 60 \mathrm{Ul} / \mathrm{mL}, A S T: 29 \mathrm{Ul} / \mathrm{mL}, \mathrm{Hb}$ : $10.2 \mathrm{gr} / \mathrm{dL}$. In the liver biopsy, the following results were found: histology activity index (HAl): 10, fibrosis: 3. On 29.6.2012, Treatment with pegylated interferon alpha-2b 80 mcg per week and ribavirin $200 \mathrm{mg}$ tb $2 \times 2$ per day was initiated. In the second phase of the treatment the ribavirin dose was reduced to 600 mg per day. The patient received intermittent blood transfusions. During the treatment process, the lowest $\mathrm{Hb}$ value was detected to be $6.5 \mathrm{gr} / \mathrm{dL}$. The patient's treatment process was completed once the dose adjustments and increased blood transfusions were carried out. HCV RNA was detected to be negative in the twelfth week of treatment. At the end of the treatment and six months after treatment (21.10.2013), sustained virological response was achieved in the patient.

\section{Discussion}

The main objectives of chronic hepatitis $\mathrm{C}$ treatment are eradication of hepatitis C virus, keeping liver inflammation under control, and preventing development of cirrhosis and hepatocellular carcinoma (10). Other underlying diseases in patients undergoing chronic hepatitis $\mathrm{C}$ treatment constitute contraindications related to the treatment. In thalassemia patients, iron accumulation in the liver and chronic HCV infection can increase fibrosis and affects the response to interferon treatment negatively (6).

With standard interferon treatment used previously in the treatment of chronic hepatitis, sustained virological response rates were found to be very low. In a meta-analysis sustained viral response rate with interferon monotherapy was identified as $25 \%$ (11). Compared to monotherapy results, sustained viral response rates have increased with combination of pegylated interferon alpha 2a/2b and ribavirin (12). Sustained viral response rates have further increased with triple treatments practiced recently $(13,14)$. Many contraindications are referred to in the treatment of chronic HCV in patients with thalassemia, depending on the medicines used. No data were found in the literature on the use of new generation medicines used in triple treatment in patients with thalassemia. Side effects observed during ribavirin administration are defined as; haemolytic anaemia, fatigue, pruritus, rash, sinusitis, birth defects or gout $(1,2$,$) . In$ the previously published guidelines, use of ribavirin in patients with thalassemia was not recommended due to its haemolytic side effect. In the guideline published in 1999, the British Association for the Study of the Liver (BASL) included anaemia and hemoglobinopathies in the list of contraindications (9). In the report by the European Association for the Study of the Liver (EASL) issued in 1999, anaemia and hemoglobinopathies were defined as definite contraindications to ribavirin (15). In its report in 2000, the Asian Pacific Association for the Study of the Liver (APASL) included renal failure, pregnancy or no reliably effective method of contraception and serious heart disease among the definite contraindications. In addition, anaemia could be considered as another salient issue for people with risks of uncontrolled hypertension and coronary artery disease among the relative contraindications (16). In its report in 2002, the National Institutes of Health $(\mathrm{NIH})$ recommended a combination therapy for the treatment of chronic HCV. Yet, the $\mathrm{NIH}$ pointed out to the fact that the combination therapy treatment is not to be administered in patients with decompensated cirrhosis and comorbidities (17). In the report of the American Association for the Study of Liver Diseases (AASLD) in 2004, acceptable haemoglobin value for men was given as $>13 \mathrm{gr} / \mathrm{dL}$, while it was $>12 \mathrm{gr} / \mathrm{dL}$ for women. Hemoglobinopathies are not addressed among the contraindications except in these laboratory data.

In a review published in the British Medical Journal in 2006, hemoglobinopathies were included among the contraindications to chronic HCV treatment (18). In the special report published in 2007 by APASL, anaemia was listed among the relative contraindications for patients who had to undergo interferon and ribavirin treatment. It was matter of concern that if the combination therapy is administered in this patient group, iron overload and the damage in the liver may increase further (1). 
As observed in all the sources listed above, we can conclude that medication is not prescribed to most of the patients diagnosed with thalassemia and chronic HCV. However, when the literature is reviewed, there appears to be very few studies on administration of interferon monotherapy and a low rate of sustained viral response was observed $(19,20,21,22)$. With the chelators used in the treatment of thalassemia major patients, cardiac complications are kept under control and life spans are prolonged. Nevertheless, chronic liver diseases play an important role in the prognosis of patients with thalassemia (10). With improved management of chronic blood disorders, concurrent problems such as chronic HCV infection can now cause greater morbidity and mortality in these patients than the diseases suffered in the first place (1).

In the light of this information, it can be seen that despite its contraindications, such as increased fibrotic changes in the liver, combination therapy can be administered with better treatment results in cases where two diseases coexist. There are very few publications of such cases in the literature. In an article, there is a reference to combination therapy which did affect interferon monotherapy or patients with recurrences; it was reported that with the treatment of interferon alpha-2b three times a week and ribavirin $1 \mathrm{gr}$ per day for a period of six months, sustained viral response rate of $45.5 \%$ was achieved in sixth month of treatment (23). This treatment option is the first case in the literature that was ever applied to patients with both thalassemia major and chronic HCV.

In a study which used a combination in the treatment of chronic HCV associated with transfusion, 14 genotype $1 \mathrm{~b}$ and 4 genotype 6a patients were followed. In the sixth month after a one-year treatment of interferon alpha $3 \mathrm{MIU} / \mathrm{m}^{2}$ three times per week and ribavirin $16 \mathrm{mg} / \mathrm{kg}$ per day, sustained viral response rate of $72.2 \%$ was achieved and there was $30 \%$ increase in blood transfusion requirement during the treatment (24). In another case report, pegylated interferon alpha $2 \mathrm{~b}$ and ribavirin combination therapy was regarded as a suitable treatment option for achieving sustained viral responses in chronic HCV and thalassemia patients who show no reaction to standard interferon treatment. However, further randomized controlled trials are needed (7). In another study where 16 patients (genotype $1 \mathrm{n}=12$, genotype 2-3 $n=4$ ) diagnosed with chronic $\mathrm{HCV}$ and thalassemia were treated with binary combination, sustained viral response rate was achieved in $50 \%$ of patients with genotype 1 type. During the treatment, blood transfusion rates increased by $30-40 \%$ (25). In a study using a low-dose of ribavirin, it was shown that treatment of patients was possible and consequently a combination therapy was proposed (26).

The dilemma resulting from the reported contraindication on one hand and the studies utilizing ribavirin on the other hand, remains to be solved. Literature review from this perspective shows that some resources have started to consider the binary treatment as appropriate. In the special report published by APASL in 2007, the consensus decisions reached with regards to the treatment of patients with thalassemia were as follows:

- Antiviral treatment should be considered in the treatment of thalassemia or haemophilia patients with chronic HCV infection (Evidence level 1),
- It is indefinite in thalassemia patients whether the combination therapy of ribavirin and peg-IFN or monotheraphy is the best choice (Evidence level 2),

- Following bone marrow transplant, after the immunomodulator therapy is stopped, HCV treatment must be considered (Evidence level 2).

Administration of pegylated interferon and ribavirin combination in this group of patients is included among the proposals of Italian Thalassemia and Hemoglobinopathies Work Group and Italian Association for the Study of the Liver (10). In the EASL 2014 guideline, emphasizing the increase in the incidence of anaemia in studies where a combination of interferon and ribavirin were applied, it is recommended that both thalassemia major and chronic HCV the binary combination treatment can be administered with blood transfusions $(27,28)$.

Within the framework of all the data hereby given, when considering the sustained viral response achieved by the binary treatment administered to the patient, we propose that Peg-IFN/ RBV combination therapy is regarded as an option in order to stop the progress of fibrotic changes of the liver. Anaemia symptoms should be carefully monitored during the treatment process and measures such as RBV dose adjustment or transfusion should be put into effect.

\section{References}

1. McCaughan GW, Omata M, Amarapurkar D, Bowden $S$, Chow WC, Chutaputti A, Dore G, Gane E, Guan R, Hamid SS, Hardikar W, Hui CK, Jafri W, Jia JD, Lai MY, Wei L, Leung N, Piratvisuth T, Sarin S, Sollano J, Tateishi R. Special report Asian Pacific Association for the Study of the Liver consensus statements on the diagnosis, management and treatment of hepatitis $C$ virus infection. J Gastroenterol and Hepatol. 2007; 22:615-633.

2. Strader DB, Wright T, Thomas DL, Seeff LB. AASLD PRACTICE GUIDELINE Diagnosis, Management and Treatment of Hepatitis C. Hepatology. 2004; 39(4):1147-1171.

3. Bircan I, Şişli S, Güven $A$, Çalı Ş, Yeğin $O$, Ertuğ $H$, Güven $A G$, Akar N. Hemoglobinopathies in the district of Antalya,Turkey. Pediatr Hematol Oncol. 1993; 10(3): 289-293.

4. Angelucci $E$, Pilo F. Treatment of hepatitis $C$ in patients with thalassemia. Haemotologica. 2008; 93(8): 1121-1123.

5. Angelucci E, Muretto P, Nicolucci A, Baronciani D, Erer B, Gaziev J, Ripalti M, Sodani P, Tomassoni S, Visani G, Lucarelli G. Effects of iron overload and hepatitis $C$ virus positivity in determining progression of liver fibrosis in thalassemia following bone marrow transplantation. Blood. 2002; 100(1): 17-21.

6. Ardalan FA, Osquei MR, Toosi MN, Irvanloo G. Synergic effect of chronic hepatitis $\mathrm{C}$ infection and beta thalassemia major with marked hepatic iron overload on liver fibrozis: a retrospective cross-sectional study. BMC Gastroenterol. 2004; 4:17.

7. Hamidah A, Thambidorai CR, Jamal R. Peginterferon Alfa-2b and Ribavirin in Thalasameia/Chronic Hepatitis C Virus-Colnfected Non-Responder to Standard Interferon-Based Therapy. Med J Malaysia 2005; 60(4): 517-519.

8. Carithers RL, Emerson SS. Therapy of hepatitis C: metanalysis of interferon alpha-2b trials. Hepatology 1997; 26: 83-88.

9. Booth JCL, O'Grady J, Neuberger J. Clinical guidelines on the management of hepatitis C. Gut 2001; 49:1-21.

10. Di Marco V, Capra M, Angelucci E, Borgna-Pignatti C, Telfer $P_{\text {, }}$ Harmatz P, Kattamis A, Prossamariti L, Filosa A, Rund D, Gamberini MR, Cianciulli P, De Montalembert M, Gagliardotto F, Foster $G$, Grangè JD, Cassarà $F$, lacono $A$, Cappellini MD, Brittenham GM, Prati D, Pietrangelo A, Craxì A, Maggio A; Italian Society 
for the Study of Thalassemia and Haemoglobinopathies; Italian Association for the Study of the Liver. Management of chronic viral hepatitis in patient with Thalassemia: reccomendatios from an international panel. Blood. 2010; 116(16): 2875-2883.

11. Tine F, Magrin $S$, Craxı $A D$, Pagliaro L. Interferon for non-A, non-B chronic hepatitis. A meta analysis of randomised clinical trials. J Hepatol. 1991; 13(2): 192-199.

12. Ghany MG, Strader DB, Thomas DL, Seeff LB. Diagnosis, management and treatment of hepatitits C: An update. Hepatology 2009; 49: 1335-1374.

13. Zeuzem S, Andreone P, Pol S, Lawitz E, Diago M, Roberts S, Focaccia R, Younossi Z, Foster GR, Horban A, Ferenci P, Nevens F, Müllhaupt B, Pockros P, Terg R, Shouval D, van Hoek B, Weiland O, Van Heeswijk R, De Meyer S, Luo D, Boogaerts G, Polo R, Picchio G, Beumont M; REALIZE Study Team. Telaprevir for retreatment of HCV infection. N Eng J Med. 2011; 364(25): 24172428.

14. Bacon BR, Gordon SC, Lawitz E, Marcellin P, Vierling JM, Zeuzem S, Poordad F, Goodman ZD, Sings HL, Boparai N, Burroughs $\mathrm{M}$, Brass CA, Albrecht JK, Esteban R; HCV RESPOND-2 Investigators. Boceprevir for previously treated chronic HCV genotype 1 infection. N Eng J Med. 2011; 364(13): 1207-1217.

15. EASL International Consensus Conference on Hepatitis C Paris 26-28 February 1999 Consensus Statement. J Hepatol. 1999; 30: 956-961.

16. Consensus statements on the prevention and management of Hepatitis B and Hepatitis C in the Asia-Pacific region. J Hepatol Gastroenterol. 2000; 15: 825-841.

17. NIH Consensus Statetement on Management of Hepatitis C: 2002 National Institutes of Health Concensus and State of the Science Statements. 2002; 19(3): 1-52.

18. Patel K, Muir AJ, McHutchison JG. Diagnosis and treatment of chronic hepatitis C infection. BMJ 2006; 332: 1013-1017.

19. Syriopoulau V, Daikos GL, Kostanidou SI, Manolaki N, Nakopoulou $L$, Kattamis A, Kattamis C. Sustained response to interferon alpha $2 a$ in thalassemicpatients with chronic hepatitis $\mathrm{C}$ : a prospective 8-year follow-up study. Haematologica 2005; 90: 129-131.
20. Artan R, Akçam M, Yılmaz A, Kocacık D. Interferon alpha monotherapy for chronic hepatitis $\mathrm{C}$ viral infection in thalassemics and hemodialysis patients. J Chemother. 2005; 17(6): 651-655.

21. Zamani F, Shakeri R, Islam M, Taheri H, Mohamadnejad M, Malekzadeh R. Interferon monotherapy in major thalassemic patients with hepatitis C infection. Govaresh. 2005; 10(3): 178182.

22. Di Marco V, Lo lacono O, Almasio P, Ciaccio C, Capra M, Rizzo M, Malizia R, Maggio A, Fabiano C, Barbaria F, Craxì A. Long-term efficacy of $\alpha$-Interferon in $\beta$-thalassemics with chronic Hepatitis C. Blood. 1997; 90(6): 2207-2212.

23. Telfer PT, Garson JA, Whitby K, Grant PR, Yardumian A, Hoffbrand AV, Wonke B. Combination therapy with interferon alpha and ribavirin for chronic hepatitis $\mathrm{C}$ virus infection in thalassaemic patients. Br J Haematol. 1997; 98(4): 850-855.

24. Li CK, Chan PK, Ling SC, Ha SY. Interferon and ribavirin as frontline treatment for chronic hepatitis $\mathrm{C}$ infection in thalassameia major. Br J Haematol. 2002; 117(3): 755-758.

25. Harmatz $P$, Jonas MM, Kwiatkowski JL, Wright EC, Fischer R, Vichinsky E, Giardina PJ, Neufeld EJ, Porter J, Olivieri N; Thalassemia Clinical Research Network. Safety and efficacy of pegylated interferon alpha 2a and ribavirin fort he treatment of hepatitis $C$ in patients with thalassemia. Haematologica. 2008; 93(8): 1247-1251.

26. Tabatabei SV, Alavian SM, Keshvari M, Behnava B, Miri SM, Karimi Elizee P, Zamani F, Amini Kafiabad S, Gharehbaghian A, Hajibeigy B, Lankarani KB. Low dose ribavirin for treatment of hepatitis $C$ virus infected thalassemia major patients: New indications for combination therapy. Hepat Mon. 2012; 12(6): 372-381.

27. EASL Clinical Practice Guidelines: Management of Hepatits $C$ Virus Infection. Journal of Hepatology. 2011; 55: 245-264.

28. EASL Clinical Practice Guidelines: Management of Hepatits C Virus Infection. Journal of Hepatology. 2014; 60: 392-420. 